\title{
History in the Making
}

January 2014

Contributors and Back Matter

Follow this and additional works at: https://scholarworks.lib.csusb.edu/history-in-the-making

\section{Recommended Citation}

(2014) "Contributors and Back Matter," History in the Making: Vol. 7 , Article 22.

Available at: https://scholarworks.lib.csusb.edu/history-in-the-making/vol7/iss1/22

This Back Matter is brought to you for free and open access by the History at CSUSB ScholarWorks. It has been accepted for inclusion in History in the Making by an authorized editor of CSUSB ScholarWorks. For more information, please contact scholarworks@csusb.edu. 


\section{Contributors}

Steven Anthony is a senior at California State University, San Bernardino. He is majoring in History with a concentration in Middle Eastern history. He has also participated in the Model United Nations team for two years.

Todd Broaddus enrolled in the teaching credential program after completing his undergraduate degree from CSUSB. He has been a teacher of students with special needs for the last twelve years. In 2012, he decided to retur to CSUSB and further his education by earning a Master of Arts in Social Sciences with an emphasis in modern European history. He plans to teach part-time at the junior college level while continuing his career in the field of special education. He would like to thank Dr. Timothy Pytell for his encouragement and expertise in European history and Dr. Robert Blackey for his invaluable input during the editing process. In addition, he would like to thank his fiancée Jessica Williams for her patience and support over the last two years.

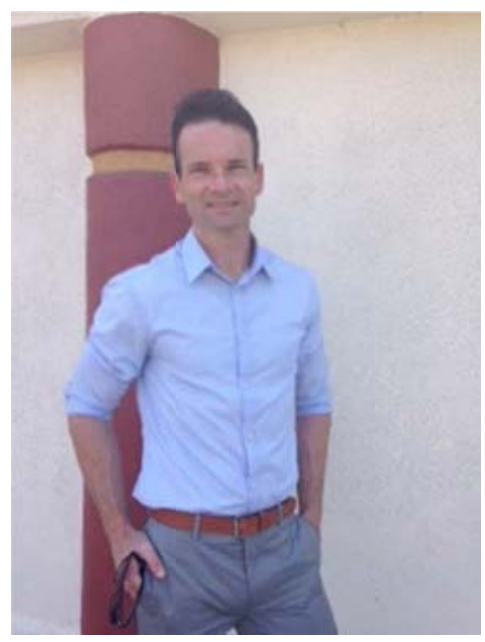


Cassie Grand is a Senior Undergraduate Student from California State University, San Bernardino. Majoring in Oral Public History, she plans to gain future work within archives or libraries after graduating in June 2014. She currently interns for Patton State Mental Hospital in San Bernardino, California. Her work there entails building an archive and museum for the hospital's wealth of history and artifacts. Cassie plans to further her education by earning a Master's Degree in Librarian Sciences.

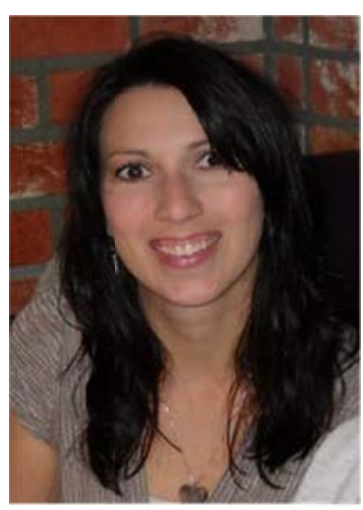

The History Club/Phi Alpha Theta at California State University, San Bernardino has established an active role on campus and within the local community. During the past two years, the club has created a foundation in the student community, with help from members of the history faculty who utilize their knowledge and abilities to effectively make a lasting impact on the campus. The History Club volunteers three days a week with Upward Bound, by tutoring local high school students on their AP exams. The club undertook fundraising events in order to create scholarships that provided these students with proper technology that would aid them throughout their college career. Additionally, the club has also volunteered at Manzanar, a historical site, for a second consecutive year to help preserve its history for future generations. The 12 Years a Slave film review is the second publication by the History Club for the History in the Making journal. This review was made possible by the dedicated members that were willing to work together. The History Club extends its appreciation to the members of the club, the editors of the journal, and the brilliant professionals in the History Department who work hard to guide the next generations of historians. Its members include: Lauren Kirschke, Jasmin Gonzalez, Moriah Schnose, and Haley Carter, who authored the 12 Years a Slave review. 
Alexandra Bethany Klee Martin is in finishing her final year at California State University, San Bernardino. She is a Psychology major with a focus in behavioral psychology. When she graduates, she hopes to be able to excel in any job oppo tunity that comes her way. After Alexandra graduates, she plans to incorporate her knowledge of history into her career.

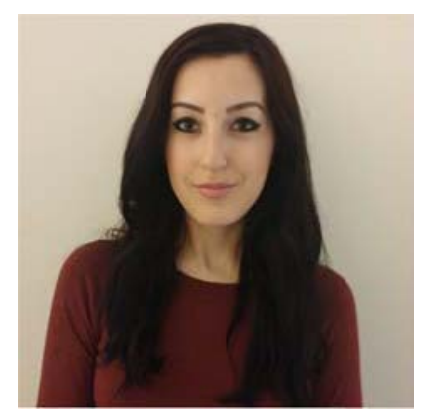

Shawn Martinez, Stephanie Reilly, and Charmaine Galley were enrolled in a topics in history course on the Silk Roads, taught by Professor Murray. At the end of January 2014, they participated in a field trip to the Natural History Museum of Los Angeles County to experience the "Traveling the Silk Roads" exhibit. The credibility to voice the opinion on the matter comes from their experiences in their respective fields of study. Shawn Martinez is a history major with a concentration in public and oral history. He has done field work at the National Archives in Riverside, interned at Pechanga, and is currently interning at March Air Field Museum in Moreno Valley, where he is helping to build and design an exhibit on the history of March Air Force Base. He will graduate in 2014. Stephanie Reilly is a history major with a concentration in European studies, specifically ancient and classical. She is a member of the history club and volunteers her time tutoring high school students through Upward Bound. Charmaine Galley is a music major with a concentration in music history and a minor in history. She volunteers at the Rialto Branch Library.

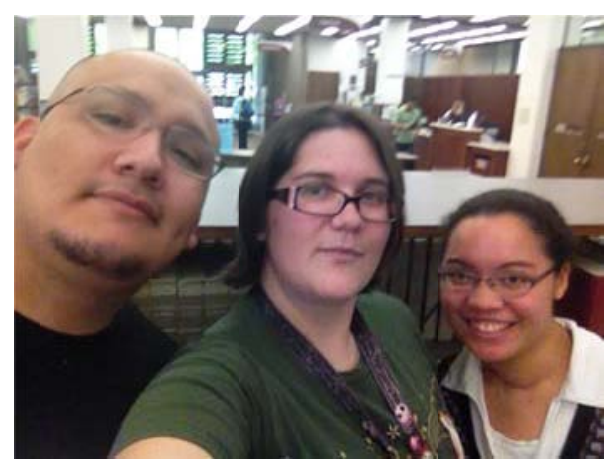


Moriah Kioko Schnose is an undergraduate student at California State University, San Bernardino, and is in her junior year. She is majoring in History with a concentration in African History. Moriah is involved with the CSUSB History Club and has plans to further her education by getting a Master's Degree in History.

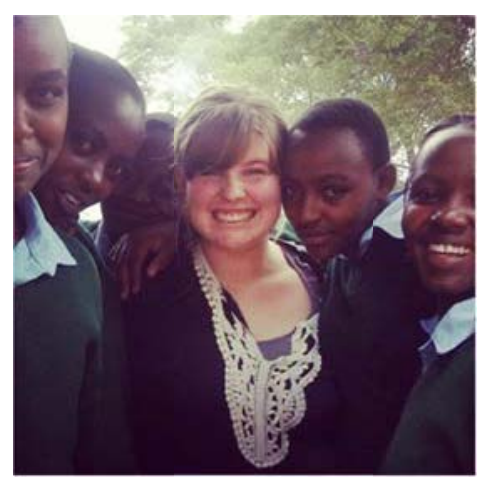

Sean Switzer graduated in 2013 with a Bachelor of Arts degree in European History from California State University San Bernardino. He enjoys traveling and spent a short time touring Israel, which inspired his studies in Middle Eastern History and his submission on Ariel Sharon. Sean occupies his time working as a chef de cuisine, experimenting with his other passion in food, preparing ethnic and fusion cuisines. He intends to one day continue his education in a graduate program and teach youth at a high school level. He would like to thank his parents for their support throughout his education as well as his editors, Ricardo Elias, Meagan Muschara, and Carole Spitler for their time and dedication. He would also like to say a special thank you to his history adviser, Dr. Yaghoubian, for his inspiring passion for instructing and challenging students at the university and guiding him through the difficulties of the research and writing process.

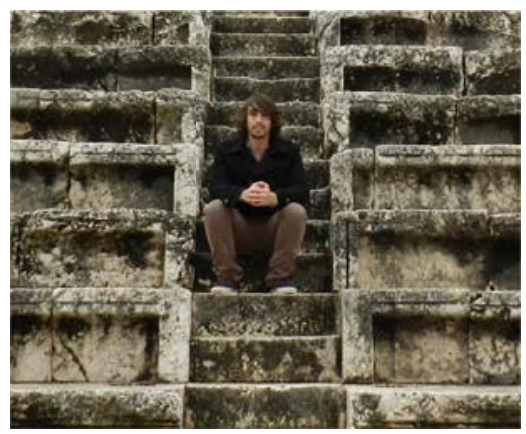


Cody August Vrba is a third year student at CSUSB. August is currently majoring in history with a minor in economics. He serves as the treasurer of the history club and works hard to promote the club's many valuable projects. History club members earned the presidential gold medal for community service in 2014 for their work with the Upward Bound program.

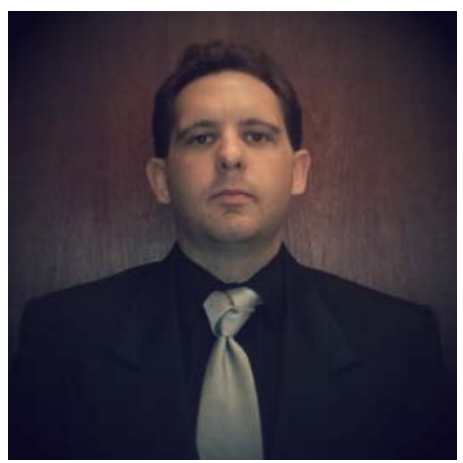


To order copies or for further information, please visit the journal website, hosted by the Department of History at California State University, San Bernardino:

http://historyinthemaking.csusb.edu 